\title{
Living together with children and elderly: the impact of family structure on the consumption of migrants and residents in urban China
}

\author{
Yueping Song ${ }^{1} \cdot$ Jingwen Zhang ${ }^{2}$
}

Received: 31 January 2018 / Accepted: 11 June 2018 / Published online: 11 July 2018

(c) Springer Nature Singapore Pte Ltd. 2018

\begin{abstract}
Using data from the first wave of the "China Family Dynamic Survey" conducted in 2014, this study compares the impact on consumption of the presence of children or elderly people in migrant households and to that in urban resident households, and then examines the extent to which lack of access to public services might explain the differences in consumption patterns that do exist. The results indicate that migrant households with infants and toddlers increase their consumption of healthcare services, while those with preschool children increase their consumption of educational services. Migrant households with elderly members significantly increase their consumption of healthcare services. The comparison of migrant households with urban resident households shows that there are considerable differences between migrant households and urban resident households in terms of how educational and healthcare expenditures are affected by the presence of children and elderly. The differences grow out of a huge gap in the accessibility of low-cost, subsidized public preschool education and government-funded health insurance programs.
\end{abstract}

Keywords Children · Elderly · Migrant households · Urban resident households · Consumption

\section{Introduction}

Along with a dramatic rise in migration overall, more and more migrants are moving as family units including spouse, children, and even elderly parents to live in cities (Duan et al. 2008; Zhai et al. 2007; Zhou 2004). The entry of migrant families

Yueping Song

songyueping@ruc.edu.cn

1 Institute of Health Science Research, Renmin University of China, Beijing, China

2 School of Sociology and Population Studies, Renmin University of China, Beijing, China 
including children and elderly into urban environments has increased the demand for child care, education, health and elderly care services. However, the access of migrant families to publicly subsidized services is limited compared to that of urban resident families. In fact, access to publicly subsidized services like child or elderly care facilities, public schools, and healthcare insurance in China is tied to an individual's household registration (hukou). People have access to such services only in the locale of their household registration. Migrant families that do not have hukou from the cities where they live cannot access the public services offered by those cities and must instead rely on private sector commercial services to meet their needs. Moreover, though many migrants are covered by government-funded health insurance programs such as the New Rural Cooperative Medical Insurance System, most of them must use healthcare services in their hometowns (where their hukou is located) to be covered by these rural insurance programs. They have no coverage for healthcare services in the cities where they reside. Instead, migrants in cities must pay for healthcare services out-of-pocket and having children or elderly in the household increases those expenses.

While it is well recognized that migrating with children and elderly increases the burdens of migrant families in cities, there has been little rigorous analysis of how the presence of elderly and children in migrant households impacts the consumption behavior of migrants in cities and how this consumption behavior differs from that of urban resident households.

Household consumption behavior, especially for migrants, can reflect the extent of the inclusiveness of social policy of the local cities. Social policy aims at providing security for families by protecting against unexpected changes to household income, and serves as an impetus for raising the level of household consumption (Leland 1968). One crucial factor that explains the low level of migrants' consumption is that they have limited access to public services like public education and social welfare programs like health insurance, so they have to pay market prices for these services. As a result, migrants have a precautionary motive to increase their savings rather than spending on other types of consumption (Chen et al. 2012). The level and structure of migrant household consumption are not only affected by household factors such as age structure and income level, but also hinge on the accessibility of social security and public services. Today, the Chinese government is actively engaged in promoting the equalization of urban public services and the social integration of migrant workers. In support of these efforts, this study provides information on how the consumption of migrant households is affected by changes in the member composition of households, and information on the nature of migrant family educational and healthcare consumption, two types of consumption closely associated with social security and public services.

Using data from the "China Family Dynamic Survey 2014" conducted by the National Health and Family Planning Commission, this paper analyzes the impact of age composition of migrant households on their consumption structure, and then compares the consumption structure of migrant and urban resident households in urban areas. The study is especially concerned with the impact the presence of children and the elderly have on household consumption. Following this introduction, Sect. 2 presents a review of relevant literature. Section 3 describes the data and 
introduces the research method. Sections 4 and 5 show the empirical findings and offer possible explanations of these findings. The paper concludes with a discussion of policy issues.

\section{Literature review}

The existing literature about the consumption of migrants focuses mainly on the consumption level of migrants and the determinants of that level. A majority of studies indicate that migrant households have lower levels of consumption due to the precautionary motive that results from their need to pay market prices for education and healthcare services (Giles and Yoo 2007; Sun and Chen 2014). Some studies have found that consumption patterns differ enormously between the most recent generation of migrants and migrant workers who immigrated earlier (Xiao 2010). In addition to common determinants like household income, other factors including barriers to urban public education systems, housing subsidies and health insurance coverage, the occupational structure of migrant workers, marital status, and family migration patterns also influence the consumption behavior of migrant workers (Kong and Li 2013). Lack of job security significantly constrains the consumption levels of migrants, while participating in the pension and unemployment insurance systems can exert a positive impact on consumption (Zhang and Liu 2015).

There is also a growing body of literature that sheds light on the effect of family structure on household consumption. Theoretically, there are two possible explanations for the relationship between family structure, especially the age composition of a household, and consumption. One is the life-cycle hypothesis, which suggests that household members plan their consumption and savings behavior over their lifecycle. They intend to even out their consumption in the best possible manner over the entire life course, doing so by saving when they earn and dis-saving when they are retired (Ando and Modigliani 1963; Modigliani and Brumberg 1954). The other is the household saving demand model (Neher 1971), arguing that parents invest in their children by bearing the costs of rearing them in anticipation of retirement when their children will, in turn, support the parents, and thus the investment in children can be viewed as a substitute for household saving. The more children a couple has, the lower the propensity to save and the higher the proportion of income that goes to consumption will be. Having few children results in the reverse case.

Most studies use macroeconomic data as empirical evidence to examine the impact changes in family structure have on consumption. However, existing studies both from China and other countries have not reached a consensus about what the empirical evidence tells us; in fact, studies sometimes come to conclusions that are contradictory. Some international papers focus on the relationship between dependency ratio and saving rate, showing that the child dependency ratio and the age dependency ratio are negatively associated with the saving rate. In other words, an increase of the dependency ratio will raise household consumption (Modigliani 1966). Moreover, according to some studies, this conclusion can apply to both developed countries and developing countries (Leff 1969). Some studies have found 
that when the proportion of working age adults to total population becomes larger, domestic consumption diminishes, confirming the life-cycle hypothesis (Erlandsen and Nymoen 2008). Adams (1971), on the other hand, maintained that a high birth rate encourages people to work harder, and increases capital accumulation and social savings, indicating that a high dependency ratio does not necessarily translate into an increase of consumption. Hurd (1990) also found that life-cycle theory is not correct in all cases. For example, the elderly may save more so they can leave bequests to their children, and such behavior should be taken into account.

The evidence from China, which is focused on the impact of aging on domestic consumption, yields different conclusions. Chen and Li (2010) found that a larger proportion of working age adults stimulates consumption and decreases the domestic savings rate. Other studies conclude that an increasing proportion of elderly in the population goes hand in hand with a swell of domestic savings and a drop in the propensity to consume (Song and Lin 2010; Yuan and Song 2000). These findings are assumed to be a result of individual rational choice working against a background of population transition (Yuan and Song 2000). Moreover, some evidence shows that population aging has a negative influence on the saving rate (Wang et al. 2004). The rise of the age dependency ratio can boost domestic consumption (Qi et al. 2012). Based on the above discussion, some studies have gone a step further to delineate the underlying mechanism that establishes the relationship between family structure and household consumption. Zhao and Dong (2013) found that a rise in the child dependency ratio leads to an increase of saving rate at first, followed by a downturn and then a rise again, while the relationship between the age dependency ratio and the saving rate is described by an inverse U-shaped curve. Moreover, they decompose the impact of age composition on savings into a "behavior effect" and an "age-structure effect". Finally, there are empirical studies that find the age dependency ratio has no significant influence on savings or consumption (Li et al. 2008).

In addition to the discussion about consumption level, some researchers highlight the relationship between the ages of family members and consumption structure. Drawing on data from statistical yearbooks on annual GDP, domestic consumption and population age composition, Yu and Sun (2012) analyzed the relationship between population aging and consumption structure. The result shows that compared with younger people, the elderly have lower demand for food, clothing and recreation, but higher demand for household equipment, transportation, telecommunications and healthcare services. Mao and $\mathrm{Xu}$ (2014) used the data from The Urban Household Survey from 2002 to 2009 and found that the elderly spent more money on food and healthcare services, while adolescents had higher expenditures on recreation and clothing, and working-age adults spent more on housing, household equipment and telecommunications.

Although many studies have examined the relationship between family structure and consumption, few research efforts have identified the difference between migrant households and urban resident households in terms of the impact of household age composition on the consumption behavior of these households. In particular, few studies focus on migrant households to present a systematic analysis of their consumption behavior and structure. This paper adopts a micro perspective to examine the relationship between age composition of household members, paying particular attention to the presence of children and elderly people, and total household 
consumption, as well as consumption of educational and healthcare services. The study focuses on migrant households, and uses urban resident households for comparison. The study also provides information that can support efforts to improve urban public services for migrant households in China.

\section{Data and methodology}

\subsection{Data description}

The study draws on data from "China Family Dynamic Survey" conducted in 2014, by National Health and Family Planning Commission. The survey provides basic demographic information about each household member and detailed information about household income and expenditure. The sample selection used in the survey is based on a stratified multistage PPS design in 31 provinces and autonomous regions/municipalities. In total, 32,500 families from 1624 sample communities of 1560 towns or urban districts were targeted and 32,494 families were actually interviewed; the sample is nationally representative. The sample for our analysis includes 2930 migrant households and 11,077 urban resident households in urban areas.

\subsection{Empirical methodology}

To assess the impact the age composition of household members has on their consumption, we estimate the effects of the presence of children of different age groups and elderly people on total consumption, and on the consumption of healthcare and educational services of migrant families. We then estimate consumption of the same items by household registration status in order to compare the effects of differential access to social welfare programs on the consumption behavior of migrant versus resident families in urban areas. One of the challenges is a data matching problem that arises because the data for consumption expenditures draws on household-level data, while age information is obtained from individual data. Mao and Xu (2014) adopted the method used by Mankiw and Weil (1989), decomposing the household consumption to individual levels. Our study uses a different approach. Instead of taking individuals as our unit of analysis, we investigate the relationship between the age composition of household members and household consumption behavior at the household level, examining whether or not having household members of certain age groups has an effect on per capita household consumption. Our method integrates the overall age composition of households into a household-level analysis.

The study provides detailed information on each household member who was interviewed. We firstly generate a set of binary variables, $D U M M Y_{j}$, which has a value of 1 if there are family members at jth age group or has a value of 0 otherwise. We divide children in households into several age groups because children of different ages have different childcare and/or educational needs. $D U M M Y_{1}$ indicates children aged 0-2 who need early childhood care, $D U M M Y_{2}$ indicates children of preschool education age 3-6, DUMMY 3 indicates children of primary school age 7-12, 
and $\mathrm{DUMMY}_{4}$ indicates children of junior middle school age 13-15. DUMMY 5 indicates the presence of elderly people aged 60 or more in a household. Thus the basic model for the effect of age composition on household consumption is given by:

$$
\begin{aligned}
\ln (\mathrm{E})= & \mathrm{a}_{1} D U M M \mathrm{Y}_{1}+\mathrm{a}_{2} D U M M Y_{2}+\mathrm{a}_{3} D U M M Y_{3} \\
& +\mathrm{a}_{4} D U M M Y_{4}+\mathrm{a}_{5} D U M M Y_{5}+\mathrm{b} X+e
\end{aligned}
$$

where $E$ denotes the household consumption expenditure for a certain product. The National Bureau of Statistics divides total household consumption into 8 subcategories: housing, food, clothing, household equipment, medicine and health, communication, education and culture, and other expenditures, all of which are included in our study. $X$ indicates the control variables, which include the log of household income, household size, hukou status (rural or urban), and the gender and education level of the household head. Household income is the total of wage income, business income, property income, and income from pensions and public transfers. In order to further control for heterogeneity across different regions, we control the county fixed effect in all regressions.

The partial derivative of $E$ with respect to $D U M M Y_{j}$ can be expressed as $E^{\prime} / E=a_{j}$. Therefore, $a_{j}(j=1,2, \ldots, 5)$ represents that ceteris paribus, compared to households that have no members of age group $j$, those with household members of age group $j$ leads to $a_{j}^{*} 100 \%$ more consumption expenditure. Finally, it should be noted that, on account of our emphasis on life-course perspective and concerns with policy implications, our categorization of age groups is not according to fixed single-year age groups or 5-year age groups, like those generally used. Instead, we formed age groups on the basis of life events including education and healthcare.

\section{Descriptive statistics}

Table 1 shows a percentage breakdown of households by size for both migrant and urban resident households. The average household size of the migrant households interviewed was 2.59 people, which is close to the average size of urban resident households (2.62). With respect to households of different sizes, there are obvious similarities between migrant households and urban resident households, with mostly two-person and three-person households. However, $20 \%$ of migrant households are single person families, and this proportion is much higher than that for urban resident families.

Table 1 Percentage breakdown of migrant and urban resident households by size

\begin{tabular}{lllc}
\hline & $\begin{array}{l}\text { Migrant } \\
\text { house- } \\
\text { holds }\end{array}$ & $\begin{array}{l}\text { Urban } \\
\text { resident } \\
\text { households }\end{array}$ & Total \\
\hline Household size (person) & 2.593 & 2.619 & 2.615 \\
One-person household (\%) & 20.0 & 13.4 & 14.1 \\
Two-person household (\%) & 35.7 & 37.5 & 37.3 \\
Three-person household (\%) & 28.5 & 25.5 & 25.8 \\
Four-person and more (\%) & 15.8 & 23.6 & 22.8 \\
\hline
\end{tabular}


According to Table 2, $10.1 \%$ of migrant households have children aged $0-2$ years in the household, while only $6.5 \%$ of urban resident households have children of this age. This disparity not only reflects different childbearing behaviors, but also means that migrant households have considerable demand for maternal and child healthcare services. The proportion of migrant households with preschoolers aged 3-6 years in the household is higher than that of urban resident households, posing a challenge for childcare services in cities. As children grow up and move to different stages of their education, they are less likely to live with their migrant parents. Only $5.9 \%$ of migrant households have children of junior high school age 13-15 in the household. Because migrant children must take the university entrance examination (gaokao) in the place where their hukou are registered, most migrant parents are forced to send their children back to the hometown in order to better prepare for the examination given in their own provinces and continue their education. Households with elderly members account for a rather small proportion of all migrant households, while on the contrary, the proportion of urban resident households with elderly household members is quite high. According to the survey, 36.6\% of urban resident households have at least one person aged 60 or over, while only $20.3 \%$ of migrant households have elderly living in the household.

Household income is the most important determinant of household consumption. The income of migrant households is somewhat higher than that of urban resident households, both in terms of total amount and per capita income. One possible explanation is that migrants may be becoming more competitive in the labor market. Nevertheless, the age composition of household members should be taken into account when considering household income. The fact that a larger share of urban resident households include elderly members may explain why, overall, the income of urban resident households is lower than that of migrant households. In addition, migrant households generally have more members of working age, and thus there are more people contributing to household income.

Despite having somewhat higher household incomes, migrant households do not take the lead so much in terms of consumption. As is shown in the Table 3, the average consumption expenditure of migrant households is RMB 59,414, which is only a bit higher than that of urban resident households.

The proportion of total household income devoted to consumption is another measure of the propensity of migrant and urban resident households to consume.

Table 2 Age composition of migrant households and urban resident households

\begin{tabular}{lrlrr}
\hline & Total & $\begin{array}{l}\text { Migrant } \\
\text { households }\end{array}$ & $\begin{array}{l}\text { Urban resident } \\
\text { households }\end{array}$ & $t$ test $(p$ value $)$ \\
\hline Mean age of household member (years old) & 44.8 & 37.1 & 45.6 & $-33.6(<0.001)$ \\
Children aged between 0-2 (\%) & 7.3 & 10.1 & 6.5 & $10.8(<0.001)$ \\
Children aged between 3-6 (\%) & 11.3 & 14.0 & 10.6 & $9.7(<0.001)$ \\
Children aged between 7-12 (\%) & 15.5 & 15.6 & 15.5 & $0.195(>0.1)$ \\
Children aged between 13-15(\%) & 6.7 & 5.9 & 6.9 & $5.8(<0.001)$ \\
The elderly aged over 60 (\%) & 33.2 & 20.3 & 36.6 & $-23.2(<0.001)$ \\
\hline
\end{tabular}


Table 3 Income and consumption of migrant households and urban resident households

\begin{tabular}{lllll}
\hline & Total & Migrant households & $\begin{array}{l}\text { Urban resident } \\
\text { households }\end{array}$ & $t$ test $(p$ value $)$ \\
\hline $\begin{array}{l}\text { Income } \\
\text { Total (RMB) }\end{array}$ & 90,299 & 100,690 & & \\
$\quad$ Per capita (RMB) & 37,086 & 44,726 & 87,686 & $5.486(<0.001)$ \\
$\begin{array}{l}\text { Consumption } \\
\text { Total (RMB) }\end{array}$ & 59,327 & 59,414 & 35,165 & $9.079(<0.001)$ \\
$\quad \begin{array}{l}\text { Per capita } \\
\text { (RMB) }\end{array}$ & 25,546 & 27,338 & 59,305 & $7.140(<0.001)$ \\
Consumption's propor- & 65.7 & 59.0 & 25,096 & $6.527(<0.001)$ \\
tion of income (\%) & & & 67.6 & \\
\hline
\end{tabular}

Here, we found that migrant households on average spend less than $60 \%$ of household income on consumption, whereas urban resident households spend $67.6 \%$ of household income on consumption. The propensity of migrant households to consume is quite low. Although many migrant families (including parents, children and elderly people) have lived in cities for extended periods of time, they are not fully recognized as urban residents and their access to social security coverage and local public services is limited compared to urban resident families. Because they have limited access to social security protections and public services, migrant families must take into account their exposure to unexpected misfortunes or setbacks when making decisions about consumption, hence they are unlikely to spend money as freely as their urban resident counterparts.

Our study focuses mainly on the consumption of healthcare services and education. As Table 4 shows, compared to food consumption, the consumption of healthcare services is significantly lower for migrant households than for urban resident households. However, different age structures between migrant households and urban resident households can be a confounding factor, leading to underestimation of the expenses of migrant households on healthcare services. This is because most migrants are working age adults who have a lower demand for healthcare. In order to identify disparities in the consumption of healthcare services among households with different hukou, we took age composition of households into consideration and did further calculations, the results of which are also shown in Table 4. With respect to households with higher demand for healthcare services, migrant households with elderly people who are over 60 pay an average of RMB 3244 every year for healthcare services, or $4.5 \%$ more than the average expenditure of urban resident households. Similarly, migrant households with children aged 0-2 also spend somewhat more on healthcare services per year. The difference provides evidence that there is a gap in the level of health insurance coverage due to hukou status. The lower level of urban health insurance coverage available to migrant households increases the burden of healthcare expenditures for these households.

With regard to education expenditure, migrant households spend more on the education of their children than do their urban resident counterparts. Migrant 
Table 4 Consumption structure of migrant households and urban resident households (RMB)

\begin{tabular}{|c|c|c|c|c|}
\hline & Total & $\begin{array}{l}\text { Migrant house- } \\
\text { holds }\end{array}$ & $\begin{array}{l}\text { Urban } \\
\text { resident } \\
\text { households }\end{array}$ & $t(p$ value $)$ \\
\hline \multicolumn{5}{|l|}{ Per capita food consumption expenditure } \\
\hline Total & 7770.8 & 8811.2 & 7509.1 & $3.465(<0.001)$ \\
\hline \multicolumn{5}{|c|}{ Per capita healthcare consumption expenditure per person } \\
\hline Total & 1966.1 & 1567.5 & 2066.4 & $-3.603(<0.001)$ \\
\hline $\begin{array}{l}\text { Household with members aged } \\
\text { between } 0-2\end{array}$ & 1377.1 & 1390.0 & 1345.9 & $0.215(>0.1)$ \\
\hline $\begin{array}{l}\text { Household with members aged over } \\
60\end{array}$ & 3127.7 & 3244.4 & 3104.2 & $0.182(>0.1)$ \\
\hline \multicolumn{5}{|c|}{ Per capita educational consumption expenditure per person } \\
\hline Total & 1874.1 & 2146.2 & 1805.7 & $2.371(<0.001)$ \\
\hline $\begin{array}{l}\text { Household with members aged } \\
\text { between } 3-6\end{array}$ & 1948.4 & 2432.9 & 1788.2 & $3.704(<0.001)$ \\
\hline $\begin{array}{l}\text { Household with members aged } \\
\text { between } 7-12\end{array}$ & 1747.9 & 2243.2 & 1625.2 & $4.217(<0.001)$ \\
\hline
\end{tabular}

households pay an average of RMB 2146 every year for education, or 18.2\% more than the average amount spent annually by urban resident households. Migrant families with preschoolers spend an average of RMB 2433 on education per year, $33 \%$ more than the average spent on preschool by urban resident families. Although preschool education is not part of China's compulsory education program, public kindergartens are funded by the government and the tuition fees paid by families are low. However, a local hukou is a prerequisite for enrollment, especially in large metropolitan areas. Migrant households do not have local hukou that give them access to public kindergartens and must purchase preschool education at market prices, paying high fees to obtain quality similar to that found in publicly funded kindergartens. Some migrant households, especially those that have come to cities from rural areas, can hardly afford the high tuition fees charged by private kindergartens. These families are forced to choose cheaper preschool institutions and accept lower quality, or give up preschool education completely. Migrants face the same issues when their children are old enough to become part of China's compulsory education system. Migrant households with children aged 7 and 12 spend an average of RMB 2243 on education each year, more than that spent by urban resident households. Thus, migrant households with children or elderly present in the household face quite different circumstances than do urban resident households.

\section{Empirical results}

In order to estimate the effects of the age composition of household members on per capita household consumption and on the consumption of healthcare services and education, we include a series of dummy variables in our models based on the 
equation. These take the value of 1 if the household has at least one family member in one of the age intervals we are concerned with, and this captures the effect of age composition. Other factors, including household per capita income, number of household members, education and gender of the household head, and the county level fix effect, are controlled to capture unobserved regional features. To further explore the difference between migrant households and urban resident households, we include the dummy variable "migration status" in model 1, assigning 1 to migrant households and 0 to urban resident households. Moreover, we divide the total sample population into two subsamples: migrant households (model 2) and urban resident households (model 3) and run the same regressions on both subsamples. Finally, based on the differences between the two types of households, we add an interaction term for "migration status" and age composition variables to model 4 to examine whether the different impacts of the presence of children of certain age groups or elderly on household consumption are significant.

\subsection{The effect of the presence of children and elderly on household per capita consumption}

Table 5 reports the estimates of the impact the presence of children of different age groups or elderly have on the per capita consumption of migrant and urban resident households. The estimates show that the age composition of household members does have a significant impact on household per capita consumption. Specifically, the presence of an infant or toddler increases household per capita consumption, whereas the presence of an elderly person leads to lower household per capita consumption (see model 1 in Table 5). The result shows that there is a significant difference in consumption between migrant households with children 0-2 years old and urban resident households with children of the same age. Rearing infants or toddlers increases a household's demand for maternal and child healthcare services. Unlike migrant households that must pay market prices for such services, urban resident households can easily get access to public resources, including free healthcare services and other support from health insurance available to urban residents. These benefits cover healthcare expenditures for urban resident households to a large extent.

Similarly, the presence of a preschooler in an urban resident household does not have a significant influence on per capita consumption, while it will significantly increase the per capita consumption of migrant households (by 9.3\%). This is because migrant households are generally excluded from the low cost public preschool education available to urban residents.

It is widely recognized that elderly people have a lower propensity to consume than younger people. For urban resident households, having a family member over 60 years old results in less consumption, but this is not the case for migrant families. This is because the elderly have greater demand for healthcare services than younger people, and migrant households are generally unable to benefit from urban health insurance systems. As a consequence they have to pay more for healthcare services and this elevates their household per capita consumption. 
Table 5 OLS estimates of per capita consumption of migrant and urban resident households

Variables

(1)

(2)

(3)

(4)

All households Migrant households

Urban resident Total households

\begin{tabular}{|c|c|c|c|c|}
\hline \multicolumn{5}{|l|}{ Years } \\
\hline $0-2$ & $\begin{array}{l}0.0161 \\
(0.0194)\end{array}$ & $\begin{array}{l}0.00868 * \\
(0.00464)\end{array}$ & $\begin{array}{l}0.0235 \\
(0.0191)\end{array}$ & $\begin{array}{l}0.0304 * \\
(0.0169)\end{array}$ \\
\hline $3-6$ & $\begin{array}{l}0.0117 \\
(0.0143)\end{array}$ & $\begin{array}{r}0.0507 * * \\
(0.0216)\end{array}$ & $\begin{array}{l}0.00,619 \\
(0.0162)\end{array}$ & $\begin{array}{l}0.00755 \\
(0.0160)\end{array}$ \\
\hline $7-12$ & $\begin{array}{c}-0.0278 * * \\
(0.0124)\end{array}$ & $\begin{array}{l}0.00973 \\
(0.0302)\end{array}$ & $\begin{array}{c}-0.0381 * * * \\
(0.0136)\end{array}$ & $\begin{array}{c}-0.0338 * * \\
(0.0135)\end{array}$ \\
\hline $13-15$ & $\begin{array}{l}0.00157 \\
(0.0168)\end{array}$ & $\begin{array}{l}0.0622 \\
(0.0420)\end{array}$ & $\begin{array}{r}-0.0120 \\
(0.0184)\end{array}$ & $\begin{array}{r}-0.00798 \\
(0.0184)\end{array}$ \\
\hline Over 60 & $\begin{array}{r}-0.00899 * \\
(0.00542)\end{array}$ & $\begin{array}{l}0.00837 \\
(0.0253)\end{array}$ & $\begin{array}{c}-0.00432 * \\
(0.0026)\end{array}$ & $\begin{array}{r}-0.00151 \\
(0.0101)\end{array}$ \\
\hline Household sizes (person) & $\begin{array}{r}-0.198 * * * \\
(0.00478)\end{array}$ & $\begin{array}{c}-0.205^{* * *} \\
(0.0128)\end{array}$ & $\begin{array}{r}-0.200 * * * \\
(0.00516)\end{array}$ & $\begin{array}{r}-0.198 * * * \\
(0.00478)\end{array}$ \\
\hline Log of per capita income & $\begin{array}{r}0.138 * * * \\
(0.00394)\end{array}$ & $\begin{array}{r}0.132 * * * \\
(0.00855)\end{array}$ & $\begin{array}{r}0.138 * * * \\
(0.00445)\end{array}$ & $\begin{array}{r}0.138 * * * \\
(0.00394)\end{array}$ \\
\hline $\begin{array}{l}\text { Hukou } \\
\qquad(1=\text { urban })\end{array}$ & $\begin{array}{r}0.0620 * * * \\
(0.0114)\end{array}$ & $\begin{array}{r}0.139 * * * \\
(0.0233)\end{array}$ & $\begin{array}{l}0.0255^{*} \\
(0.0135)\end{array}$ & $\begin{array}{r}0.0606 * * * \\
(0.0114)\end{array}$ \\
\hline $\begin{array}{l}\text { Gender of the head } \\
(1=\text { female })\end{array}$ & $\begin{array}{r}0.0385 * * * \\
(0.00820)\end{array}$ & $\begin{array}{r}0.0658 * * * \\
(0.0186)\end{array}$ & $\begin{array}{r}0.0283 * * * \\
(0.00916)\end{array}$ & $\begin{array}{r}0.0385^{* * * *} \\
(0.00820)\end{array}$ \\
\hline Year of education of the head & $\begin{array}{r}0.0246 * * * \\
(0.00126)\end{array}$ & $\begin{array}{r}0.0207 * * * \\
(0.00304)\end{array}$ & $\begin{array}{r}0.0249 * * * \\
(0.00140)\end{array}$ & $\begin{array}{r}0.0247 * * * \\
(0.00127)\end{array}$ \\
\hline $\begin{array}{c}\text { Migration status } \\
\text { (1= Migrant) }\end{array}$ & $\begin{array}{c}-0.0389 * * * \\
(0.0116)\end{array}$ & & & $\begin{array}{c}-0.0587 * * * \\
(0.0154)\end{array}$ \\
\hline$* 0-2$ years old & & & & $\begin{array}{r}-0.0460 \\
(0.0284)\end{array}$ \\
\hline$* 3-6$ years old & & & & $\begin{array}{r}0.0218 * * \\
(0.0092)\end{array}$ \\
\hline$* 7-12$ years old & & & & $\begin{array}{l}0.0321 \\
\quad(0.0271)\end{array}$ \\
\hline$* 13-15$ years old & & & & $\begin{array}{l}0.0517 \\
(0.0410)\end{array}$ \\
\hline *over 60 years old & & & & $\begin{array}{r}0.0523 * * \\
(0.0244)\end{array}$ \\
\hline County fix effect & Yes & Yes & Yes & Yes \\
\hline Observations & 14,007 & 2930 & 11,077 & 14,007 \\
\hline$R$-squared & 0.478 & 0.510 & 0.492 & 0.478 \\
\hline
\end{tabular}

$* * *, * *$ and $*$ denote statistical significance at the levels $0.01,0.05$ and 0.10 , respectively 


\subsection{The effect of the presence of children and elderly on household consumption of education}

One focus of this research is to examine whether access to publicly subsidized services can help to explain differences in consumption between migrant and urban resident households that have children in specific age groups or elderly people present in the household. Because educational and healthcare services are key public services for households, our analysis is focused on the consumption of education and healthcare services.

In this section, we examine how the presence of children of different age groups in a household affects the household consumption of educational services for migrant households and urban resident households, respectively (see model 1 to model 4 in Table 6). The regression results show that, for all households, having a household member aged 3-6, 7-12, or 13-15 significantly increases educational expenditure. As Table 6 shows, the coefficient of having a household member aged 7-12 or 13-15 is lower for migrant households compared with urban resident households that have children in these age groups. This is because migrant children aged 7-15 can also benefit from low cost public education as do their peers from urban resident families. Therefore migrant households, like urban resident households, are not faced with extra expenditures to pay for compulsory education. Meanwhile, urban families are more likely to invest in additional educational services; for example, paying for cram schools and private tutors for their children that result in higher household consumption for education services. In other words, the results do not indicate that migrant households and urban resident households have different levels of accessibility to public education services, but reflect that the latter spend more on additional or better quality educational services for their children. This might serve to further widen the educational gap between migrant children and children from urban resident families.

In the case of children aged 3-6, migrant households with children in this group have significantly higher expenditures for educational services than do urban resident households (model 4 in Table 6). Although preschool education is not a part of China's compulsory education program, many kindergartens and preschools in urban areas are publicly funded, and migrant children are excluded from these facilities. Instead, migrant families must purchase higher priced child care or preschool services from private institutions. Although a few migrant households have relatively high socioeconomic status and can afford to send their children to better private preschools, most migrant families are unable to pay costly tuition fees and must turn, instead, to informal preschool institutions or give up preschool education completely. Because they have unequal access to publicly funded educational services and must pay for such services out-of-pocket, the ability of migrant families to consume other kind of goods and services is stunted.

\subsection{The effects of the presence of children or elderly on healthcare consumption of migrant and urban resident households}

As Table 7 shows, the effect on healthcare consumption of having children or elderly in the household differs between migrant households and urban resident households. 


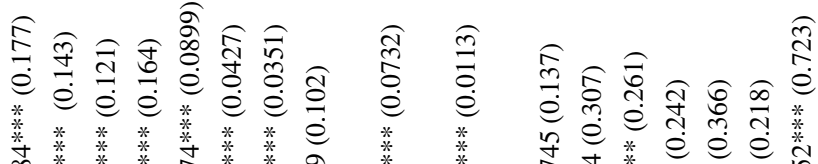

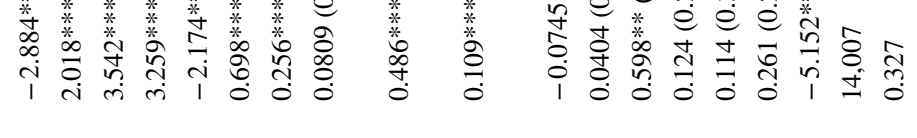

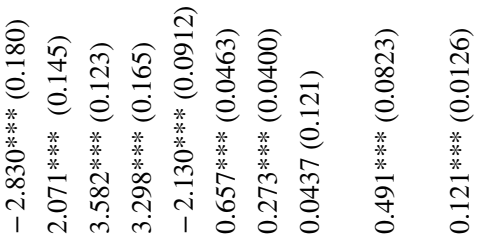

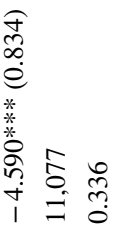

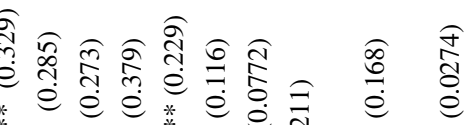
* * e e

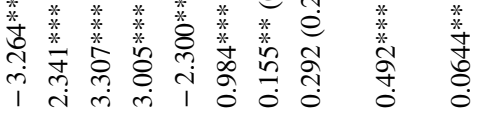

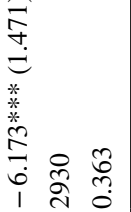

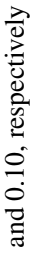

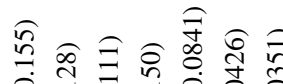
* eे é

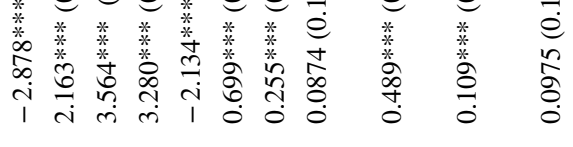

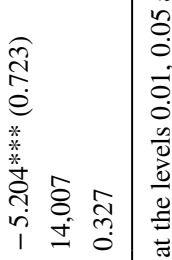

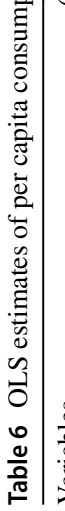


For migrant households, having children under 6 years old or elderly people aged 60 or more significantly increases the consumption of healthcare services. Per capita healthcare consumption increases by 53\% if the household has a child aged 0-2 and $75.5 \%$ if the household has a child aged 3-6. The effects of the presence of children in these age groups is not significant for urban resident households. In the case of the elderly, the consumption of healthcare services increases by $156.9 \%$ on average in urban resident households with an elderly person present and $173.6 \%$ on average in migrant households. The difference between the two types of households is significant as indicated by model 4 in Table 7.

There are huge differences in the levels of health insurance coverage migrants and residents of cities have. In addition to having less coverage than urban residents, migrants also receive lower reimbursements for services than urban residents. Some migrant households even have to bear the entire cost of healthcare services themselves. Most urban residents are covered by some type of healthcare insurance. Many urban families with children or elderly household members are part of the Urban Residents Basic Medical Insurance program, which provides coverage for the healthcare expenditures of children and elderly residents. Lack of access to the healthcare insurance programs available to urban residents places financial burdens on migrant families that have children and/or elderly living in the household in urban areas.

\section{Conclusion and discussion}

Migration is a major feature of China's ongoing economic transformation. As of 2017, 245 million (NHCPRC 2017) migrants had traveled to cities in search of opportunity. Providing migrants with equal access to basic public services in urban areas is a priority as the urbanization process continues. However, lack of access to public resources and services is one of the many obstacles migrant families confront in urban areas, and this problem has yet to be resolved. This is especially the case with respect to the costs of child care and the inability of migrants to participate in urban health insurance programs. The fact that migrant households must pay child care costs out-of-pocket constrains migrant consumption of other kinds of goods and services.

This study uses the data from the "China Family Dynamic Survey 2014" to investigate the effects that the presence of children and elderly on the consumption of migrant households and urban resident households. The results suggest that for migrant households, having an infant or toddler in the household significantly increases consumption of healthcare services. Migrant households with preschool or school-aged children spend more on educational services than comparable urban resident households. In the case of households with elderly members, both migrant and urban resident households showed considerable increases in expenditures for healthcare services, but the amount of increase was greater for migrant households. The empirical analysis shows that the presence of children and elderly has significantly different effects on the consumption of migrant households versus urban resident households. In the case of consumption for educational and healthcare services, 
Table 7 OLS estimates of per capita healthcare consumption expenditure

\begin{tabular}{|c|c|c|c|c|}
\hline Variables & $\begin{array}{l}\text { (1) } \\
\text { All households }\end{array}$ & $\begin{array}{l}\text { (2) } \\
\text { Migrant households }\end{array}$ & $\begin{array}{l}\text { (3) } \\
\text { Urban resident } \\
\text { households }\end{array}$ & $\begin{array}{l}(4) \\
\text { Total }\end{array}$ \\
\hline \multicolumn{5}{|l|}{ Years } \\
\hline $0-2$ & $\begin{array}{r}0.329 * * \\
(0.135)\end{array}$ & $\begin{array}{l}0.530^{*} \\
(0.298)\end{array}$ & $\begin{array}{l}0.187 \\
\quad(0.155)\end{array}$ & $\begin{array}{l}0.170 \\
\quad(0.154)\end{array}$ \\
\hline $3-6$ & $\begin{array}{r}0.327 * * * \\
(0.111)\end{array}$ & $\begin{array}{r}0.755^{* * *} * \\
(0.258)\end{array}$ & $\begin{array}{l}0.177 \\
\quad(0.125)\end{array}$ & $\begin{array}{l}0.149 \\
\quad(0.124)\end{array}$ \\
\hline $7-12$ & $\begin{array}{r}-0.184 * \\
(0.0964)\end{array}$ & $\begin{array}{l}0.0253 \\
\quad(0.247)\end{array}$ & $\begin{array}{c}-0.276 * * * \\
(0.106)\end{array}$ & $\begin{array}{c}-0.306^{* * * *} \\
(0.105)\end{array}$ \\
\hline $13-15$ & $\begin{array}{c}-0.586 * * * \\
(0.131)\end{array}$ & $\begin{array}{r}-0.445 \\
(0.343)\end{array}$ & $\begin{array}{c}-0.656 * * * \\
(0.142)\end{array}$ & $\begin{array}{c}-0.684 * * * \\
(0.143)\end{array}$ \\
\hline Over 60 & $\begin{array}{r}1.598 * * * \\
(0.0732)\end{array}$ & $\begin{array}{r}1.736^{* * * *} \\
(0.207)\end{array}$ & $\begin{array}{l}1.569 * * * \\
(0.0786)\end{array}$ & $\begin{array}{l}1.520 * * * \\
(0.0782)\end{array}$ \\
\hline Household sizes (person) & $\begin{array}{l}0.117 * * * \\
(0.0371)\end{array}$ & $\begin{array}{r}0.361 * * * \\
(0.105)\end{array}$ & $\begin{array}{l}0.0672 * \\
(0.0399)\end{array}$ & $\begin{array}{l}0.113 * * * \\
(0.0371)\end{array}$ \\
\hline Log of per capita income & $\begin{array}{l}0.0431 \\
\quad(0.0306)\end{array}$ & $\begin{array}{l}0.0773 \\
\quad(0.0699)\end{array}$ & $\begin{array}{l}0.0209 \\
\quad(0.0344)\end{array}$ & $\begin{array}{l}0.0433 \\
\quad(0.0306)\end{array}$ \\
\hline $\begin{array}{l}\text { Hukou } \\
(1=\text { urban })\end{array}$ & $\begin{array}{l}0.118 \\
\quad(0.0887)\end{array}$ & $\begin{array}{r}0.578 * * * \\
(0.191)\end{array}$ & $\begin{array}{r}-0.0264 \\
(0.104)\end{array}$ & $\begin{array}{l}0.108 \\
\quad(0.0888)\end{array}$ \\
\hline $\begin{array}{l}\text { Gender of the head } \\
(1=\text { female })\end{array}$ & $\begin{array}{l}0.258 * * * \\
(0.0637)\end{array}$ & $\begin{array}{r}0.480 * * * \\
(0.152)\end{array}$ & $\begin{array}{l}0.173 * * \\
(0.0709)\end{array}$ & $\begin{array}{l}0.253 * * * \\
(0.0637)\end{array}$ \\
\hline Year of education of the head & $\begin{array}{c}-0.0285 * * * \\
(0.00983)\end{array}$ & $\begin{array}{c}-0.0572 * * \\
(0.0248)\end{array}$ & $\begin{array}{r}-0.0198 * \\
(0.0108)\end{array}$ & $\begin{array}{c}-0.0277 * * * \\
(0.00983)\end{array}$ \\
\hline \multicolumn{5}{|l|}{ Migration status } \\
\hline$(1=$ Migrant $)$ & $\begin{array}{r}-0.136 * * \\
(0.0605)\end{array}$ & & & $\begin{array}{c}-0.552 * * * \\
(0.119)\end{array}$ \\
\hline$* 0-2$ years old & & & & $\begin{array}{l}0.619 * * \\
(0.267)\end{array}$ \\
\hline$* 3-6$ years old & & & & $\begin{array}{r}0.765^{* * * *} \\
(0.227)\end{array}$ \\
\hline$* 7-12$ years old & & & & $\begin{array}{r}0.622 * * * \\
(0.211)\end{array}$ \\
\hline$* 13-15$ years old & & & & $\begin{array}{l}0.513 \\
\quad(0.318)\end{array}$ \\
\hline *over 60 years old & & & & $\begin{array}{r}0.507 * * * \\
(0.190)\end{array}$ \\
\hline Constant & $\begin{array}{r}4.798 * * * \\
(0.629)\end{array}$ & $\begin{array}{r}3.971 * * * \\
(1.332)\end{array}$ & $\begin{array}{r}5.136 * * * \\
(0.718)\end{array}$ & $\begin{array}{r}4.908 * * * \\
(0.629)\end{array}$ \\
\hline Observations & 14,007 & 2930 & 11,077 & 14,007 \\
\hline$R$-squared & 0.194 & 0.230 & 0.203 & 0.196 \\
\hline
\end{tabular}

$* * *, * *$ and $*$ denote statistical significance at the levels $0.01,0.05$ and 0.10 , respectively

the age composition of the family has a greater impact on migrant households than it does on urban resident households. In order for all family members to live together in a city, migrant households must bear higher costs for certain services due to their 
limited access to public services. The fact that migrants must pay out-of-pocket for these services dampens migrant demand for the consumption of other kinds of goods and services.

Much work is still needed to formulate effective policies that promote family development opportunities for migrants by supporting equalization of access to public services for migrant households in cities. Preschool educational services are in desperate short supply for migrants living in urban areas. Providing sufficient public preschool educational services for migrant households would be an effective measure to promote equal access to child care services and relieve migrant families of the burden of having to pay out-of-pocket for preschool. Moreover, migrating with young children or the elderly greatly increases household demand for healthcare services. Increasing the access of migrant households to health insurance and increasing the reimbursement levels for services are both essential to reducing the out-of-pocket costs for healthcare services paid by migrant families. Policy initiatives should support publicly funded insurance programs that are portable, providing continuing coverage for families as they migrate from region to region, and that close the gap between reimbursement levels in urban and rural areas.

Acknowledgements This research is supported by "Beijing Social Science Fund" (No.15JGB077) of China.

\section{References}

Adams, N. A. (1971). Dependency rates and savings rates: comment. American Economic Review, 61(3), $472-475$.

Ando, A., \& Modigliani, F. (1963). The "life cycle" hypothesis of saving: aggregate implications and tests. American Economic Review, 53(1), 55-84.

Chen, R., \& Li, X. (2010). Changes of population structure and saving rate of urban and rural residents in China. Academia Bimestrial, 3, 169-173.

Chen, B., Lu, M., \& Zhong, N. (2012). Hukou and consumption heterogeneity: migrants' expenditure is depressed by institutional constraints in urban China. Social Science Research Network electronic journal. https://doi.org/10.2139/ssrn.1989257.

Duan, C., et al. (2008). Nine trends of population migration in China since the reform and opening up. Population Research, 32(6), 30-43.

Erlandsen, S., \& Nymoen, R. (2008). Consumption and population age structure. Journal of Population Economics, 21(3), 505-520.

Giles, J., \& Yoo, K. (2007). Precautionary behavior, migrant networks, and household consumption decisions: An empirical analysis using household panel data from rural China. The Review of Economics and Statistics, 89(3), 534-551.

Hurd, M. D. (1990). Research on the elderly: economic status, retirement, and consumption and saving. Journal of Economic Literature, 28(2), 565-637.

Kong, X., \& Li, J. (2013). An analysis of the elements affecting farm workers' consumption in our countrya study based on the data from 1860 samples in 28 provinces and regions across China. Journal of Shaanxi Normal University (Philosophy and Social Sciences Edition), 42(1), 24-33.

Leff, N. H. (1969). Dependency rates and savings rates. American Economic Review, 59(5), 886-896.

Leland, H. E. (1968). Saving and uncertainty: the precautionary demand for saving. Quarterly Journal of Economics, 82(3), 465-473.

Li, W., Xu, C., \& Ai, C. (2008). The impacts of population age structure on household consumption in China: 1989-2004. Economic Research Journal, 7, 118-129.

Mankiw, N. G., \& Weil, D. N. (1989). The baby boom, the baby bust, and the housing market. Regional Science and Urban Economics, 19(2), 235-258. 
Mao, R., \& Xu, J. (2014). Demographic transition, consumption structure disparities and industrial growth. Population Research, 38(3), 89-103.

Modigliani, F. (1966). The life cycle hypothesis of saving: the demand for wealth and the supply of capital. Social Research, 33(2), 160-217.

Modigliani, F., \& Brumberg, R. (1954). Utility analysis and the consumption function: an interpretation of the cross-section data. New Jersey: Rutgers University Press.

National Health Commission of the People's Republic of China. (2017). Report on China's migrant population development 2017. Beijing: China Population Publishing House.

Neher, P. A. (1971). Peasants, procreation, and pensions. American Economic Review, 61(3), 380-389.

Qi, D., et al. (2012). A study of the effect of China population age structure on consumption. Journal of Audit and Economics, 27(4), 95-103.

Song, B., \& Lin, X. (2010). The effect of population changes in age structure urban residents' consumption behavior. Population and Economics, 4, 11-17.

Sun, H., \& Chen, L. (2014). Consumption Behavior of Rural-to-urban Migrants: Based on a Survey in Xi'an City. Population Research, 38(2), 92-101.

Wang, D., Cai, F., \& Zhang, X. (2004). The saving effect and growth effect of population changes: the population determinants of sustainable growth in China. Population Research, 28(5), 2-11.

Xiao, J. (2010). The study on consumption behavior of "new generation migrant workers". Modern Business, 26, 277-278.

Yu, X., \& Sun, M. (2012). A study of the impact of the aging of population in China on consumption. Jilin University Journal Social Sciences Edition, 52(1), 141-147.

Yuan, Z., \& Song, Z. (2000). The age composition of population, the endowment insurance system and optimal savings ratio in China. Economic Research Journal, 11, 24-32.

Zhai, Z., Duan, C., \& Bi, Q. (2007). The floating population in Beijing: an update. Population Research, 31(2), 30-40.

Zhang, H., \& Liu, S. (2015). The impacts of unemployment risk on migrants' consumption. Economic Review, 2, 68-77.

Zhao, W., \& Dong, L. (2013). Demographic structure, saving and economic growth based on PVAR model. Studies of International Finance, 9, 29-42.

Zhou, H. (2004). Study on trend and determinants of migration familization in China. Population Research, 28(6), 60-69.

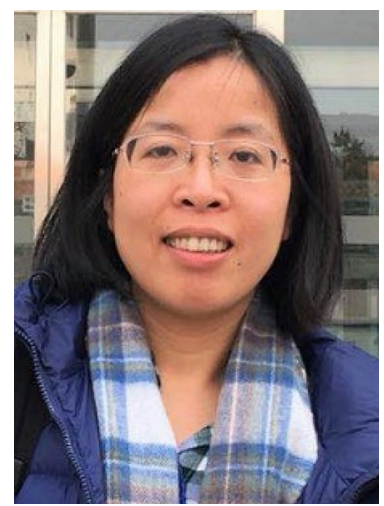

Song Yueping is now an associate professor working in Research Institute of Health, Renmin University of China. Her research interest lies in migration, gender and health. 


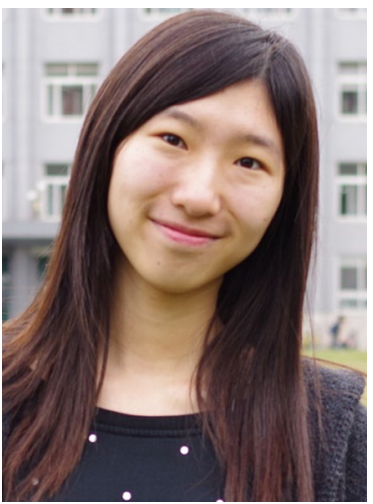

Zhang Jingwen is a graduate student at the School of Sociology and Population Studies of Renmin University of China. Her research interest is related to Maternal and Child health. 